\section{E A Institute of \\ YK Business Administration \\ 光 \\ Karachi \\ Leadership and Ideas for Tomorrow}

\section{Business Review}

Volume 3 Issue 2 July-December 2008

$7-1-2008$

\title{
Back Matter of Volume 3 Number 2
}

Tufail A. Qureshi

Institute of Business Administration, Karachi, Pakistan

Follow this and additional works at: https://ir.iba.edu.pk/businessreview

Part of the Computer Sciences Commons

c) (i)

This work is licensed under a Creative Commons Attribution 4.0 International License.

\section{Recommended Citation}

Qureshi, T. A. (2008). Back Matter of Volume 3 Number 2. Business Review, 3(2), 1-4. Retrieved from https://doi.org/10.54784/1990-6587.1158

This article is brought to you by iRepository for open access under the Creative Commons Attribution 4.0 License and is available at https://ir.iba.edu.pk/businessreview/vol3/iss2/12. For more information, please contact irepository@iba.edu.pk. 


\section{NEWS and VIEWS}

\section{$5^{\text {th }}$ EUROPEAN SYMPOSIUM ON GENDER AND ICT 2009 BREMEN, GERMANY}

Call for Contributions

5th European Symposium on Gender \& ICT

"Digital Cultures: Participation - Empowerment - Diversity"

University of Bremen, Germany, March 5-7, 2009

Information Society with its variety of new information and communication media offers many new options to participate in today's social, cultural, political and economic activities. However, chances are still distributed unequally, e.g. by class, ethnicity, age - and by gender. Access to and the ability to use information and communication technology (ICT) are necessary prerequisites for participation. On top of this, involvement in ICT design is a highly prestigious activity. On the 5th European Gender and ICT Symposium we will take a closer look at the complex interdependence between gender and ICT. We will explore ways to increase appreciation of diversity in design and use and to strengthen empowerment and participation by means of ICT. This Conference, the fifth in a row of symposia held in Europe since 2003, traditionally provides a meeting point for researchers from various disciplines and research schools dealing with gender and ICT. We invite you to share your experiences, in particular regarding the following topics:

* Gendering in Design

What values are present in society and inscribed in technology and how can they be deconstructed? With what kinds of assumptions and values about technologies, users and society do designers work? Whose values and experiences are represented and what dichotomies and stereotypes are repeated in technologies and technological cultures?

* Computing Science - a Gendered Discipline?

Where do we find women it ICT? What barriers do they encounter? In what way are their lives being supported (or not) by technology? How is gender inscribed in the concepts and culture of the discipline of computing? What structures further such inscriptions? What is needed for 'un-doing gender' in computing science?

* Gender \& Technology Curricula 
What should students learn about 'gender and technology'? In what way is it possible to integrate such contents into curricula of technical disciplines?

* Competences in Technology/Digital Media and Social Participation

How does school education integrate Digital Media? What does media competence mean? Where and how does gendering happen in girls' and boys' education? What best practices can guide the way towards an education that offers equal opportunities for social participation?

* Digital Cultures, Identity and Subject Construction

What gender expectations are suggested? What hidden norms and values are inscribed in computer games and other software? How is identity constructed online? What possibilities do online communities offer for the construction of the self?

* Gender, Work and ICT

In what economic branches do we find so-called 'female work'? What kind of computer support can be found in these areas? How does software design affect work processes and how does it reflect job images? What measures are taken and what are the results?

* Design for Gender \& Diversity

How can gender be used as an eye-opener for diversity in design? What other groups' requirements are poorly represented in today's technology?

* Globalisation and Local Action

What effects does the development of new ICTs have - on the global and on the local level? How do global changes affect the local and vice versa? How does ICT influence gender relations in developing countries?

Please submit extended abstracts of about 3 pages (max. 10.000 characters) describing projects and research results via the conference homepage http://www.gict2009.de. Every submission will be blind reviewed by three members of the program committee. Accepted abstracts will be published on the conference- 
https://ir.iba.edu.pk/businessreview/vol3/iss2/12

DOI: https://doi.org/10.54784/1990-6587.1158

Business Review - Volume 3 Number 2

July - December 2008

website. Work in progress and late breaking results can be presented by means of posters. These have to be described on two pages (max. 6.000 characters).

Submission of abstracts September 1, 2008.

Notification of acceptance October 1, 2008

Submission of posters January 15, 2009

Notification of acceptance February 1, 2009

Program chairs

Prof. Dr. Susanne Maass

Prof. Dr. Heidi Schelhowe

Conference organisation

Maike Heckt

Anja Kümmel

Carola Shirmer

Susanne Maass

Heidi Schelhowe

If you have got any questions concerning the symposium, please contact us at gict@informatik.uni-bremen.de

University of Bremen

Computer Science Department

Postbox 330440

28334 Bremen

Germany

Phone (49) 421 - 21864390

Fax (49) 421 - 2189864390

Mail: gict@informatik.uni-bremen.de

http://www.gict2009.de 
After the failure of his quixotic hopes for Concept of the Corporation, Drucker, as noted, expects less from big business and big labor; his explicit vision narrows. But implicitly, and connected to no vulnerable programmatics like the self-governing plant community, Drucker's social idealism never leaves him. His criticism of market capitalism and its theoretical rationale remains fundamental. "Capitalism," he writes at the end of The Practice of Management, "is being attacked not because it is inefficient or misgoverned but because it is cynical. And indeed a society based on the assertion that private vices become public benefits cannot endure, no matter how impeccable its logic, no matter how great its benefits.

First and last, Peter Drucker is a moralist of our business civilization. And just as we don't read George Orwell for his answers to the social and political problems he explores but for his moral clarity and depth, so we don't come to Drucker looking for three-point plans to fix creation. He offers suggestions, he affirms the values at stake, some times he points in the right direction; but he offers few solutions and those he does offer he intends as no more than notes toward a solution. Montaigne offered no solutions, either. It is enough for the moralist to mark the distance between what is and what could be.

\section{Jack Beatty}

The World According to Drucker, p. 108 